\title{
ON THE IMPORTANCE OF THE SOWING TIME OF CRUCIFERS IN PREVENTING THE DAMAGE CAUSED BY CABBAGE MAGGOTS (Hylemyia spp), ON THE BASIS OF TESTS MADE ON BIG-LEAFED TURNIP
}

\author{
AnNa-LiISA VARIS \\ Department of Pest Investigation, Agricultural Research Centre, \\ Tikkurila \\ Received October 15th 1958
}

Studying the control of the cabbage root fly (Hylemyia brassicae Bouché) and the turnip root fly (Hylemyia floralis Fall.) several investigators have drawn attention to whether the damage caused by the cabbage maggots can be prevented by a choice of the sowing time. Vodinskaja (3) reports that the damage caused by $H$. brassicae can be reduced by an early planting of cabbage seedlings. LunDBLAD, on his part, maintains that it is not possible to sow the plants so early that their development would have advanced far enough to enable them to escape the danger from the cabbage maggots. According to his studies, the cabbage maggots prefer to live in the young plants, though they do not despise the older ones, either.

The chances of avoiding the damage by choosing the sowing time are limited by the fact that the flying and oviposition times of different species occur at very different times. The number of eggs laid by the Hylemyia-species on the root of 40 cabbages (or swedes) were counted every week during a period of several years (1941, 1945 - 1949) at Tikkurila. It was noted that the ovipesition started either towards the end af May or in the beginning of June [usually about a week after the birdcherry (Prunus padus L.) had started flowering], and continued until the beginning of September, sometimes even later. The number of eggs, however, varied considerably in different periods of the summer, the peak of the oviposition being reached by the first generation of $H$. brassicae in June and by $H$. floralis in July-August. In addition there was the oviposition of the partial second generation of $H$. brassicae as well as the oviposition of the smaller and economically less important species, $H$. florilega Zett. and $H$. fusciceps Zett. The former has partly three, the latter partly two generations in a year (1).

Another difficulty in arranging the sowing time lies in the fact that the proportional quantities of the different species vary considerably in different years. Accord- 


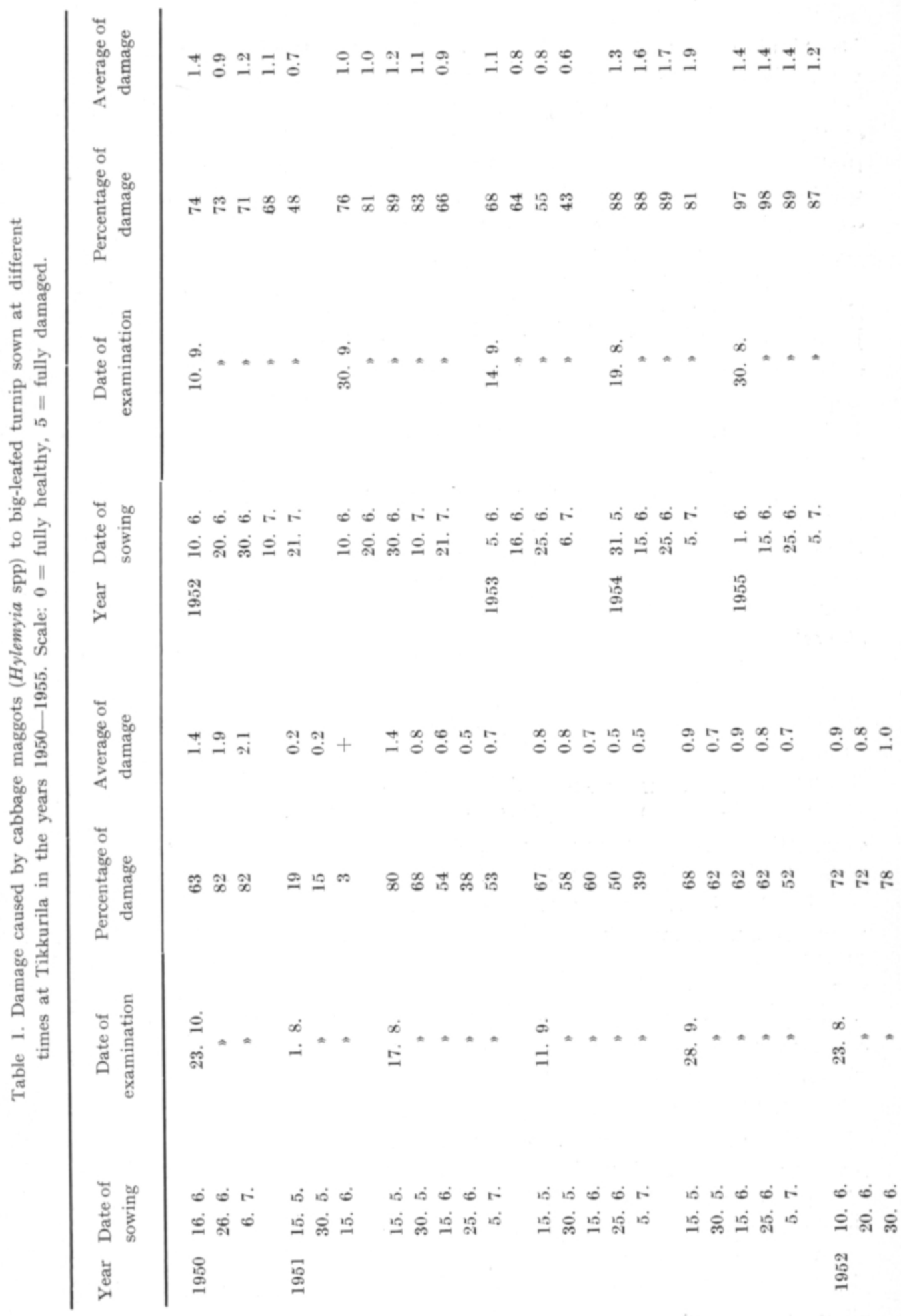


ing to the samples taken continually during the growth period $H$. floralis constituted $53-85$ per cent and $H$. brassicae 5-30 per cent of the total material, in the above years; the percentage of $H$. florilega varied between $3-15$ and that of $H$. fusciceps between $2-7$ (1). During the years of this investigation the proportion of $H$. floralis of the total material taken at Tikkurila, 1952-1955, continually decreased so that in the extensive material of 1955 (the material consisted of more than 5000 specimens) only a few specimens occurred, $H$. brassicae being the most abundant species. At Rovaniemi, again, $H$. floralis was the most common species in every year of the investigation (1951-1953).

For the examining of the importance of the sowing time the big-leafed turnip (Brassica rapa L. v. rapifera Metzg.) was considered a suitable test plant by the Department of Pest Investigation. This plant develops very quickly which makes rather late sowing possible. The extensive sowing and harvesting time tests of the Department of Plant Husbandry were used as material for this investigation at Tikkurila (lat. $60^{\circ} 20^{\prime} \mathrm{N}$. and long. $25^{\circ} 30^{\prime}$ E.) in $1950-1955$ [the information regarding the yields is taken from the tables published by YLLÖ in 1956 (4)], and the tests of the Agricultural Research Centre, Polar Circle Agricultural Experiment Station, at Rovaniemi (lat. $66^{\circ} 35^{\prime} \mathrm{N}$. and long. $26^{\circ} \mathrm{E}$.). The percentages of damage found in the different times of examination are presented in Tables 1 and 2. The number of damaged roots is given in percentages. The average severity of damage is also mentioned. A total of 200 big-leafed turnips from each member was examined at each given time.

\section{The tests at Tikkurila}

The results of the tests at Tikkurila are presented in Table 1.

At the end of October in 1950 an examination was made of three different sowing times. The damage was most severe in the latest sowing; the yield obtained from it was smaller than that obtained from the first two sowings.

The test in 1951 was made up of five sowing times, and was thus harvested at five separate dates: July 28th, August 16th and 27th, September 11th and 28th. The big-leafed turnips of the first sowings started growing before the spring humidity had completely vanished from the soil, and they were thus in a somewhat more advantageous position than those sown later. The highest yield was obtained from the big-leafed turnip sown on May 30th, but the yields obtained from the first sowing, in the middle of May, and from the third, in the middle of June, were not far behind. The yields of green and dry matters as well as that of crude protein of the first and second sowings were richest at the end of August, those of the third sowing at the beginning of September, those of the fourth sowing in the middle of September and those of the fifth sowing at the end of September. In general, the damage in the first sowings was more severe than in the later ones.

When the severity of the damage caused by the cabbage maggots is examined at the dates of examination approximately corresponding to the dates presented above, the following table is obtained: 


$\begin{array}{cccc}\begin{array}{c}\text { Date of } \\ \text { sowing }\end{array} & \begin{array}{c}\text { Date of } \\ \text { harvesting }\end{array} & \begin{array}{c}\text { Percentage } \\ \text { of damage }\end{array} & \begin{array}{c}\text { Average of } \\ \text { damage }\end{array}\end{array}$

$\begin{array}{rccc}15.5 & 17.8 . & 80 & 1.4 \\ 30.5 . & \text { " } & 68 & 0.8 \\ 15.6 . & 11.9 . & 60 & 0.7 \\ 25.6 . & \text { " } & 50 & 0.5 \\ 5.7 . & 28.9 . & 52 & 0.7\end{array}$

This table also shows the damage in the first sowings to be more severe than in the late ones.

The sowing time test of 1952 was also made up of five sowing times, the first date being June 10th. Because of the early spring the main oviposition of $\mathrm{H}$. brassicae had evidently taken place before this sowing had started to grow. The oviposition continued, and the other species participated in the damage, which in the beginning was most severe in the first and third sowings. The seedlings of the bigleafed turnips sown in June 30th had emerged at the same time as the $H$. floralis had its apparent peak of oviposition, and for this reason they were somewhat more severely damaged. By the last examination, at the end of September, the damages between different sowings became more equal. The test was harvested at three dates: August 22nd, and September 10th and 29th. The greatest yields of dry matter and crude protein were obtained from the first and second sowings at the beginning of September. The most profitable time of harvesting for the third sowing, which also gave a high yield, was the end of September, as well as for both of the last sowings, the yields obtained from these being, however, considerably smaller than those from the earlier sowings. The damage caused by the cabbage maggots at the controlling times approximately corresponding to the harvesting times given above was as follows:

\begin{tabular}{cccc}
\hline $\begin{array}{c}\text { Date of } \\
\text { soving }\end{array}$ & $\begin{array}{c}\text { Date of } \\
\text { harvesting }\end{array}$ & $\begin{array}{c}\text { Percentage } \\
\text { of damage }\end{array}$ & $\begin{array}{c}\text { Average } \\
\text { of damage }\end{array}$ \\
\hline 10.6. & 10.9. & 74 & 1.4 \\
20.6. & 30. & 73 & 0.9 \\
30.6. & 9. & 89 & 1.2 \\
10.7. & $"$ & 83 & 1.1 \\
21.7. & " 6. & 66 & 0.9 \\
\hline
\end{tabular}

According to this examination the damage was also most severe in the bigleafed turnip of the first and third sowings.

In 1953 an investigation was made of four different sowing times on September 14th. The damage proved most severe in the first sowing and slightest in the last 
one. $H$. brassicae was the most common species, constituting $60-70$ per cent of the samples taken from the big-leafed turnip, the rest of the species being distributed approximately evenly between the three other species. The best yields were obtained from the second and first sowings.

The material in 1954 consisted of an abundance of $H$. brassicae and relatively large amounts of the $H$. florilega and $H$. fusciceps species. The damage increased as from the early sowings to the late ones. Although the early part of the summer was dry the best yield was obtained from the first sowing. A particularly poor yield was obtained from the big-leafed turnip sown on July 5th.

In 1955 the damage caused by the cabbage maggots was examined in the bigleafed turnips of four different sowing times at the end of August. The last sowing was damaged least of all. The best yield was obtained from the first sowing.

\section{The tests at Rovaniemi}

The results of the tests at Rovaniemi are presented in Table 2.

The damage in the years 1951-1953 was most severe in the big-leafed turnips of the earlier sowings and it generally decreased towards the later ones.

In 1951 the best yield was obtained from the first two sowings, the yield of the third sowing was a little smaller and the yields obtained from the big-leafed turnip sown on June 16th and June 23rd were very much smaller - the latter less than a half of the best yields obtained from the first sowings. The test was by way of a demonstration so that the results can only be considered approximate.

Table 2. Damage caused by cabbage maggots (Hylemyia spp) to big-leafed turnip sown at different times at Rovaniemi in 1951-1953. Scale: $0=$ fully healthy, $5=$ fully damaged.

\begin{tabular}{|c|c|c|c|c|c|}
\hline & Year & $\begin{array}{l}\text { Date of } \\
\text { sowing }\end{array}$ & $\begin{array}{c}\text { Date of } \\
\text { examination }\end{array}$ & $\begin{array}{l}\text { Percentage } \\
\text { of damage }\end{array}$ & $\begin{array}{c}\text { Average of } \\
\text { damage }\end{array}$ \\
\hline & \multirow[t]{5}{*}{1951} & 26. 5 . & 8. 9. & 64 & 1.1 \\
\hline & & 2. 6. & , & 51 & 0.9 \\
\hline & & 9. 6 . & , & 45 & 0.6 \\
\hline & & 16. 6. & , & 47 & 0.6 \\
\hline & & 23. 6. & , & 40 & 0.5 \\
\hline & \multirow[t]{5}{*}{1952} & 27. 5 . & 6.-7. 8 & 99 & 2.7 \\
\hline & & 3. 6 . & , & 99 & 2.3 \\
\hline & & 10. 6. & , & 96 & 1.6 \\
\hline & & 17. 6. & , & 84 & 1.9 \\
\hline & & 24. 6 . & , & 91 & 1.6 \\
\hline & \multirow[t]{3}{*}{1953} & 9. 6 . & 24. 8 . & 71 & 0.9 \\
\hline & & 16. 6. & , & 65 & 0.8 \\
\hline & & 23. 6 . & , & 63 & 0.9 \\
\hline
\end{tabular}


In 1952 the green matter yields obtained from the big-leafed turnip sown at different times were as follows (metric tons per hectare): I 50.4, II 22.6, III 17.6, IV 9.0, V 2.7. The best yield was obtained from the first sowing despite the fact that the damage caused by the cabbage maggots in it was most severe. The yields showed a distinct drop in the later sowing times. The abundant occurrence of the Diamond back-moth (Plutella maculipennis Curt.) somewhat hampered the test.

In 1953 the yields of the three sowing times were harvested as follows: I on August 27th, II on September 3rd, and III on September 10th. The best yields were obtained from the big-leafed turnips sown on June 9 th and 16 th. The ratio of the yield obtained from the sowing on June 23rd was 63 (the ratio of the sowing on June 9 th being $100=46.8$ metric tons per hectare).

\section{Discussion}

The damage caused by the cabbage maggots was generally not very severe during the years studied here; the year 1952 at Rovaniemi being an exception, since the examination made at the beginning of August showed the average damage in the big-leafed turnips of the first sowing as being 2.7 while the percentage of damaged roots was 99 . - Some differences have occurred regarding the damage in different sowing times, but in South-Finland these have varied in different years. This variation was partly caused by the changes in the proportional quantities of the species and also by the weather conditions during the growth period and during the whole year, as these either directly prevented or favoured the activities of the flies affecting in this way also the proportional quantities of the species. As these points can not be estimated in advance with any accuracy, it seems that the choosing of the sowing time does not give profitable results even with a plant growing as fast as the big-leafed turnip. In South-Finland, where it is easier to choose the sowing time owing to the length of the summer, the flying time of the flies is also of such long duration that eggs occur pretty well throughout the whole summer. In North-Finland $H$. brassicae and $H$. floralis seem to appear more simultaneously and for a shorter period so that choosing the sowing time could here be considered as a means to more healthy yields. Postponing the sowing time as late as possible could in that case be considered, preferably until the middle of July. The yields show, however, that the best results are obtained from the early sowings even when the damage has been fairly severe, and that the conditions of growth show a distinct weakening with the postponing of the sowing time. In that way the yields obtained from the big-leafed turnip sown about midsummer have been significantly smaller than those sown early in June. As the early sowings carried out at the end of May or in the beginning of June have proved to be the most profitable ones in SouthFinland, and as, on the other hand, the severity of damage caused by the cabbage maggots varies yearly in regard to the different sowing times, this does not limit the early sowings. As regards the big-leafed turnip the purpose of its use naturally influences the choosing of the sowing time. 


\title{
$S u m m$ ar $y$
}

In investigating the importance of the sowing time of crucifers in preventing the damage caused by the cabbage maggots (Hylemyia spp) the big-leafed turnip (Brassica rapa L. v. rapifera Metzg.) was used as a test plant.

In regard to the abundance and severity of the damage differences occured in the test plants sown at different times. In South-Finland, however, the order varied in different years so that damage caused by the cabbage maggots can generally not be avoided by an arrangement of the sowing time. In North-Finland the early sowings were generally somewhat more severely damaged than the later ones. The postponement of the sowing time, however, had a detrimental effect on the yields and despite the fairly severe damage the best yields were obtained from the early sowings.

\section{REFERENCES:}

(1) Kanervo, V. 1954. Grönsaksflugornas biologi och bekämpning. Nord. jordbr.forskn. $36: 333-334$.

(2) Lundblad, O. 1933. Kálflugorna. Stat. växtskyddsanst.medd. 3: 1-103.

(3) VodinskajA, K. L. 1928. On the Biology and Ecology of Hylemyia brassicae Bché and Hylemyia floralis Fall. Izv, otd. prikl. ent. Leningrad 3: 229-249. (Ref. Rev. Appl. Ent. 1929: 141143).

(4) YLLÖ, L. 1956. Ưber den Einfluss der Anbautechnik auf den Ertrag der Blattrübe in Finnland. Acta agr. fenn. 91: 1-164.

S E L OS T U S :

\begin{abstract}
RISTIKUKKAISKASVIEN KYLVÖAJAN MERKITYKSESTÄ KAALIKÄRPÄSTOUKKIEN (Hylemyia spp.) AIHEUTTAMIEN TUHOJEN EHKÄISYSSÄ NAATTINAURIILLA SUORITETTUJEN KOKEIDEN PERUSTEELLA.
\end{abstract}

ANNA-LiISA VARIS

Tuhoeläintutkimuslaitos, Tikkurila

Kylvöajan merkitystä on selvitetty Tikkurilassa ja Rovaniemellä järjestettyjen kylvö- ja korjuuaikakokeiden yhteydessä. Sopivana koekasvina on pidetty naattinaurista, koska se kehittyy nopeasti, ja se voidaan täten kylvää myös melko myöhään.

Eri kylvöaikojen välillä on kaalikärpäsvioitukseen nähden ollut jonkin verran eroja. Etelä-Suomessa vioituksen runsauden ja voimakkuuden mukainen järjestys on kuitenkin vaihdellut eri vuosina, joten kylvöajan järjestelyllä ei yleensä voida välttää kaalikärpäsvioitusta.

Pohjois-Suomessa on aikaisissa kylvöksissä yleensä ollut jonkin verran enemmän vioitusta kuin myöhäisissä. Kylvőajan siirtyessä myöhäisemmäksi sadot ovat kuitenkin laskeneet tuntuvasti, ja kohtalaisen runsaasta vioituksesta huolimatta parhaat sadot on saatu aikaisista, Rovaniemen seudulla toukokuun lopulla ja kesäkuun alussa suoritetuista kylvöistä.

Kylvőajan valinnalla ei siis kaalikärpäsvioituksen kannalta näytä olevan käytännöllistä merkitystä niinkään nopeasti kasvavalla kasvilla kuin naattinauriilla. 